\title{
REDUÇÃO DE CUSTO E AUMENTO DE VIDA ÚTIL EM CAÇAMBAS DE CARREGADEIRAS USANDO AÇO DE ALTA RESISTÊNCIA E RESISTENTE AO DESGASTE MICRO LIGADOS AO NIÓBIO*
}

\author{
Hugo Leandro Rosa ${ }^{1}$ \\ Mac Kinley Ferreira Cardoso ${ }^{2}$ \\ Érico França ${ }^{3}$ \\ Leonardo Magalhães Silvestre 4 \\ Marcos Alexandre Stuart Nogueira ${ }^{5}$ \\ Jorge Luis Barreto ${ }^{6}$
}

\section{Resumo}

A CBMM aplicou aços micro ligados ao nióbio em dois tipos de caçambas de carregadeiras de rodas que operam na usina de Araxá, Brasil. O objetivo foi avaliar os benefícios destes aços relacionados com redução dos custos, aumento da produtividade e vida útil dos componentes. Uma das máquinas analisadas coleta peças quentes de ferro nióbio para carregamento dos silos do britador. O uso de um aço ferramenta de alta resistência e resistente ao desgaste solucionou os problemas de deformação, desgaste e rachaduras durante o serviço, aumentando a vida útil da caçamba em cerca de $190 \%$. A outra máquina avaliada foi uma carregadeira de rodas que opera na mina de minério de nióbio. $O$ novo desenho com aços de alta resistência mecânica e resistente ao desgaste reduziu o peso em $14 \%$, correspondendo ao incremento na capacidade de carga. A carga extra possibilitou um aumento na produtividade dos caminhões de 42 toneladas. Com os novos materiais, as trincas anteriormente encontradas na caçamba da pá carregadeira foram eliminadas, enquanto foi mantida a resistência ao desgaste antes oferecida pelo aço revestido com carbeto de cromo reduzindo também os custos de investimento em $7 \%$.

Palavras-chave: Carregadeiras de rodas; Caçambas; Aço; Resistência ao desgaste; Nióbio.

\section{REDUCING COST AND INCREASING LIFE CYCLE IN LOADER BUCKETS USING HIGH STRENGTH STEEL AND WEAR RESISTANT STEEL MICROALLOYED NIOBIUM \\ Abstract}

CBMM applied niobium microalloyed steels in two types of buckets of wheel loaders operating at its facility in Araxá, Brazil. The objective was to evaluate the benefits of these steels related to cost reduction, productivity and component life cycle. One of the analyzed machines collects hot pieces of ferroniobium after ingot stripping and loads them into crusher silos. The use of wear resistant steel and tool steel solved the problems of deformation, wear and cracks during service, increasing bucket life by about $190 \%$. The other evaluated machine was a wheel loader operating at the niobium ore mine. The new design with wear resistant and high strength steels reduced bucket weight by $14 \%$, with a corresponding increase in load capacity. The extra capacity made loading the 42-tonne mine trucks more productive. With the new materials, the cracks that previously occurred in the buckets wheel loaders were eliminated, while the same wear resistance of the original chromium carbide clad steel was retained. Furthermore, investment costs were reduced by $7 \%$.

Keywords: Wheel loaders; Buckets; Steel; Wear resistant; Niobium.

1 Mechanical Engineer, Graduate Degree in maintenance management, Head of Department. Maintenance, CBMM - Companhia Brasileira de Metalurgia e Mineração, Araxá, Minas Gerais, Brazil

2 Mechanical Engineer, Specialized in Automation and Control, Industrial Maintenance Manager, CBMM Companhia Brasileira de Metalurgia e Mineração, Araxá, Minas Gerais, Brazil

3 Material Engineer, Sênior analisys, Technology Development Deártament, CBMM - Companhia Brasileira de Metalurgia e Mineração, São Paulo, SP, Brazil.

4 Metarllugical Engineer, Mananger of Tecnology Development, Technology Development, CBMM - Companhia Brasileira de Metalurgia e Mineração, São Paulo, SP, Brazil

5 Metarllugical Engineer, Metalurgy Doctor, Director of Tecnology Development, Technology Development, CBMM - Companhia Brasileira de Metalurgia e Mineração, São Paulo, SP, Brazil.

6 Technical Mining, Head of Department. Mine, COMIPA - Companhia Mineradora do Pirocloro de Araxá, Araxá, MG, Brazil. 


\section{INTRODUCTION}

CBMM strives to provide niobium technology to develop applications where the element can help to overcome the key challenges faced around the world: growing wisely and sustainably. In order to accomplish this, CBMM employs a technical group that works with steelmakers, research universities, institutes and end users. This technology program sponsors the development of materials that maximize raw material consumption by increasing component life cycles and optimizing process efficiencies to save energy and raw materials. A component of the program includes testing developed concepts on equipment operating at CBMM facilities in Araxá, Brazil.

Higher strength and wear resistant steels are critical to create structures that are more resistant, and to use less material in components that must withstand harsh working conditions. The loaders for different operations at CBMM facilities in Araxá face many challenges since they work in abrasive conditions, suffer oxidation and, in some cases, are submitted to high temperatures.

The driving motivation for this development was to improve loading efficiency by applying high strength and wear resistant steels in buckets wheel loaders in the form of niobium microalloyed steels. The present paper provides two examples of bucket loaders using these steels and the resulting benefits.

\subsection{Description of the two analyzed buckets wheel loaders operating at CBMM facilities}

\subsubsection{Stripped FeNb ingot loader}

After being processed in electric arc furnaces, liquid ferroniobium (FeNb) is cooled in molds. Following solidification, the FeNb is stripped from the molds and collected by a loader for crusher feeding, as showed by Figure 1. During this transport operation, the $\mathrm{FeNb}$ can be at temperatures of up to $350{ }^{\circ} \mathrm{C}$.

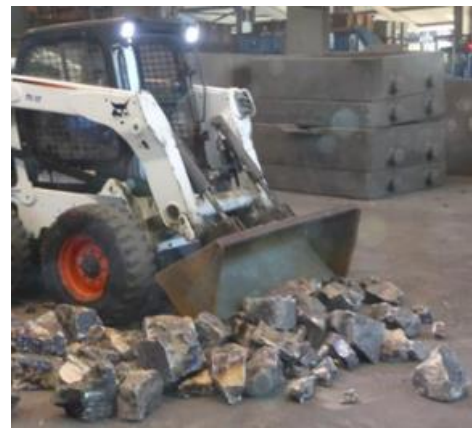

Figure 1. Loader collecting FeNb after ingot stripping.

FeNb remains in the bucket no longer than 10 minutes, but since the material is hot, the buckets suffer temperature-related deformation and cracks, as exemplified in Figure 2. 


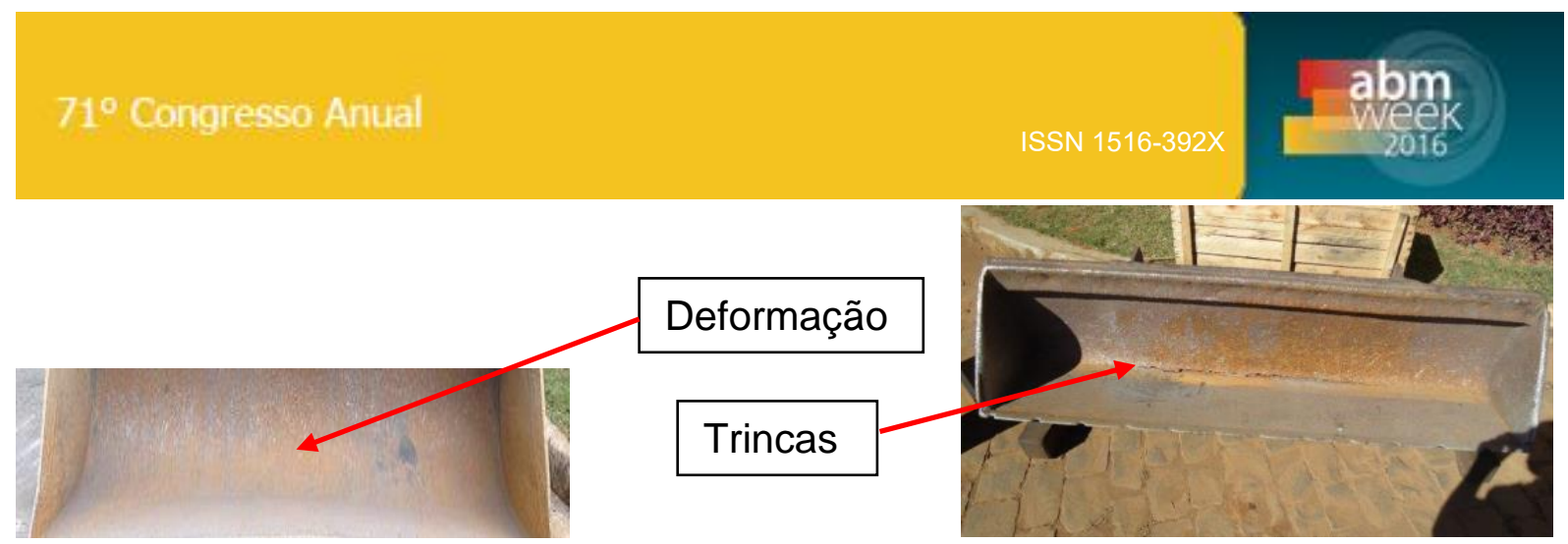

Figure 2. Deformation and cracking in backet after 200 hours in service.

The normal average service life of this kind of bucket had been 320 hours, with the best performance reaching 570 hours. The new bucket was developed to increase service life, and eliminate the cracking and deformation that makes it very difficult to collect FeNb from the floor.

\subsubsection{Bucket of Wheel loader used in the mine of Niobium ore.}

The second developed bucket was for wheel loaders with niobium ore at CBMM's mine, as exemplified in Figure 3. The main problem with the original bucket was the appearance of structural cracks, as showed by Figure 4. Service life for these components is reduced by the cracks since they start to appear at 1,600 hours to 2,000 hours of work time. The goal is to achieve total service life over 11.000hours. The buckets wheel loaders experience very little wear, this only being a consideration for the ground engaging tools (GET). GET wear will be not addressed the current paper.

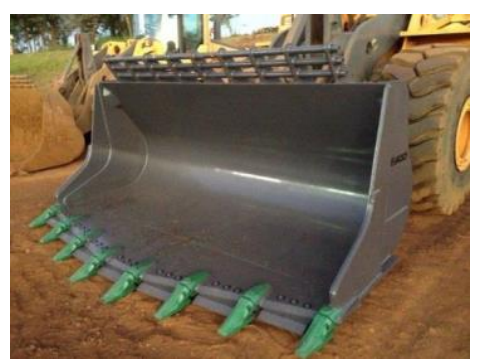

Figure 3. Weel loader at niobium ore mine.

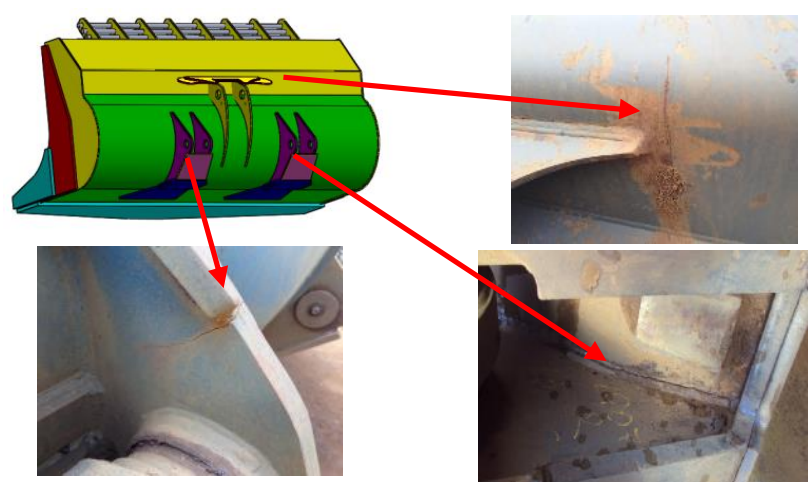

Figure 4. Structural cracks in the ore loader bucket after $2,000-3,000$ hours of work time.

\subsection{Light design and the application of wear resistant materials}

The light design concept has been very well developed for different applications [1-5]. Niobium is the unique element that increases the mechanical strength of steel and toughness simultaneously, and now there are many papers reporting niobium's effect on wear resistance as well [6-7]. By increasing steel strength, it is possible to use lean 
structures, with correspondent reductions in weight. Since toughness is also increased, structural integrity is improved. As bucket weight decreases, loading capacities increase, leading to gains in operational efficiency.

The life cycle of the buckets of wheel loaders, especially the service life the buckets, can be extended by using wear resistant steels.

\section{MATERIALS AND DESCRIPTION OF THE DEVELOPED COMPONENTS}

\subsection{Loading of FeNb after ingot stripping}

The Figure 5 shows the bucket design, including selected dimensions. The bucket weighs about $364 \mathrm{Kg}$ and has a volume of $0.24 \mathrm{~m}^{3}$. The original model was made with carbon steel grades, as exemplified in Figure 6. Because microalloyed steels were used in the new bucket, the acquisition investment was $42 \%$ higher than the original model. This investment must achieve payback through increased service life and lower maintenance.
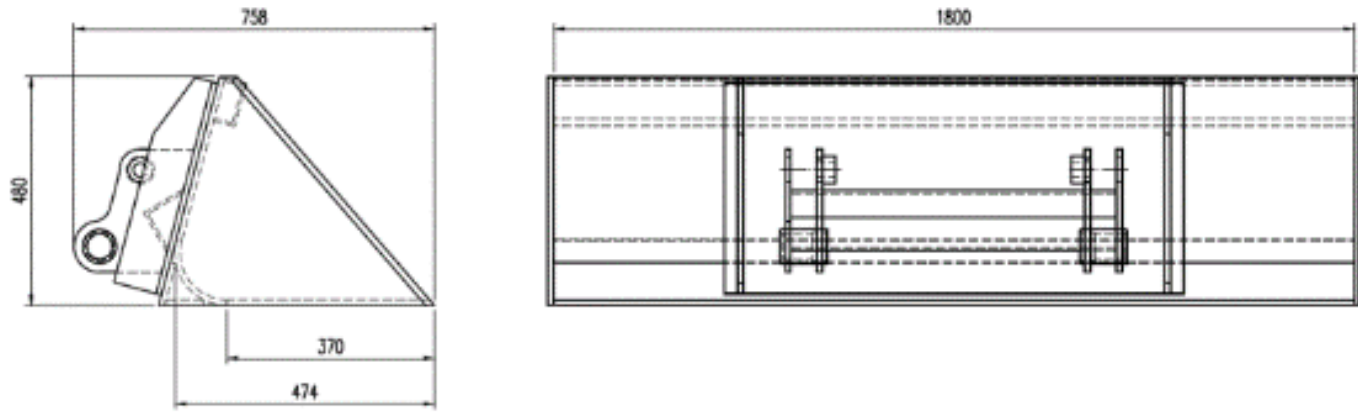

Figure 5. Main dimensions of the bucket that works with hot FeNb. Weight $=364 \mathrm{Kg}$ and vol. $=0.24 \mathrm{~m}^{3}$.
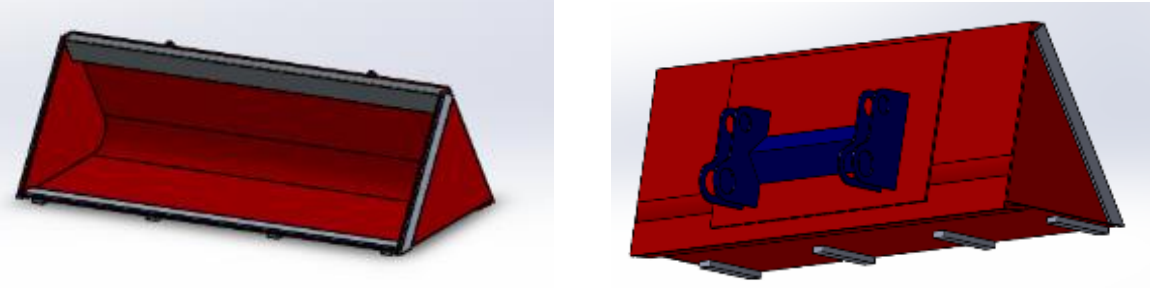

High Carbon Steel $-19.0 \mathrm{~mm}$

ASTM A36 - $15.9 \mathrm{~mm}$

ASTM A36- $15.9 \mathrm{~mm}$

Figure 6. Steels used in the original bucket that transports hot FeNb.

\subsection{Bucket of wheel loader applied in to Niobium ore.}

The Figure 6 shows the design and selected dimensions of the bucket for the ore. The bucket weighs about $3,508 \mathrm{Kg}$ and has a volume of $4 \mathrm{~m}^{3}$. This bucket was originally made with carbon steel grades and the internal face was plated with chromium carbide, as exemplified in Figure 7. The trucks have a 42-tonne capacity to haul niobium ore from the mine to the ore conveyor belt that links to the homogenization yard. The original buckets had a $10,370-\mathrm{Kg}$ rating per manufacturer specifications. Since it is impossible to achieve the maximum allowed load in real work conditions, more than 
four bucket loads were necessary to fill the truck. Therefore, an increase in bucket capacity to achieve loading the truck with four buckets would be highly beneficial. The investment cost of the original bucket was US $\$ 20,606$ per unit.
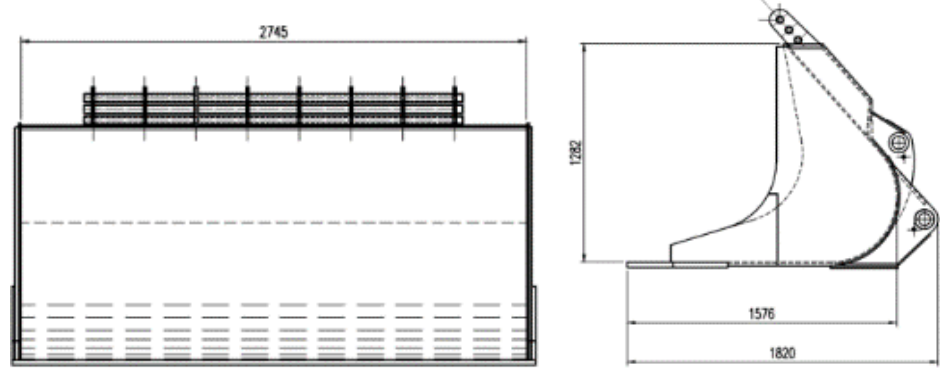

Figure 6. Main dimensions of niobium ore loader bucket. Weight $=3,508 \mathrm{Kg}$ and volume $=4 \mathrm{~m}^{3}$.
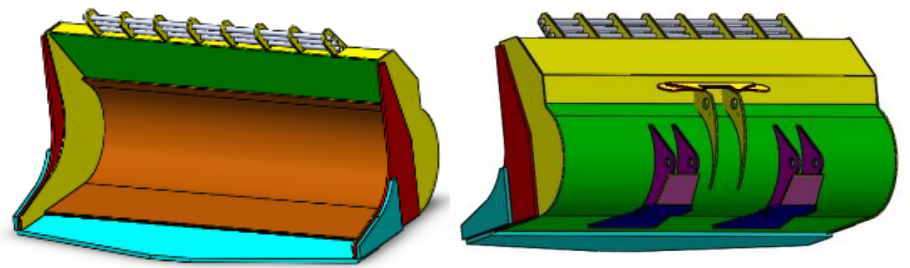

Chromium plated carbon steel $\mathbf{- 1 2 . 7} \mathbf{m m}$

High Carbon Steel- $31.75 \mathrm{~mm}$

High Carbon Steel - 22.2 mm

High Carbon Steel - $19.0 \mathrm{~mm}$

ASTM A709 50 - $9.5 \mathrm{~mm}$

ASTM A709 $50-15.8 \mathrm{~mm}$

ASTM A709 50 - $9.5 \mathrm{~mm}$

Figure 7. Steels used in the niobium ore loader bucket

\subsection{Steels}

Table 1 presents the chemical composition of the steels used in the new bucket designs. Table 2 shows the typical mechanical properties of the steels [8].

Table 1. Steels used in bucket structures.

\begin{tabular}{|c|c|c|c|c|c|c|c|c|c|c|}
\hline Steel & C & Si & Mn & $\mathbf{P}$ & $\mathrm{S}$ & $\mathrm{Cr}$ & $\mathrm{Ni}$ & Mo & Other & $\mathrm{Nb}$ \\
\hline ASTM A36 & 0.25 & 0.50 & 1.70 & 0.035 & 0.035 & - & - & - & - & - \\
\hline N High Carbon Steel & 00.32 & 0.4 & 11.5 & 00.03 & 00.015 & 0.8 & - & 0.4 & $\begin{array}{l}\text { B } 50 \% \\
\text { ppm }\end{array}$ & -- \\
\hline ASTM A709 50 & 0.23 & 0.40 & 1.35 & 0.04 & 0.05 & - & - & - & $\begin{array}{l}\mathrm{Cu}- \\
0.20\end{array}$ & - \\
\hline $\begin{array}{l}\text { Tool steel for plastic } \\
\text { mold }\end{array}$ & 0.26 & 1.08 & 0.80 & 0.008 & 0.004 & 1.35 & 0,66 & 0.80 & $\begin{array}{l}V- \\
0.14\end{array}$ & 0.015 \\
\hline $\begin{array}{c}\text { Structural steel YS } \\
>700 \mathrm{MPa}\end{array}$ & 0.063 & 0.062 & 1.790 & 0.017 & 0.003 & - & - & - & $\begin{array}{l}V- \\
0.010\end{array}$ & 0.060 \\
\hline Wear resistant steel & 0.16 & 0.21 & 1.37 & 0.011 & 0.003 & 0.15 & 0.10 & - & $\begin{array}{c}B \\
0.001\end{array}$ & 0.012 \\
\hline $\begin{array}{l}\text { High strength } \\
\text { structural steel with } \\
\text { good welding } \\
\text { properties }\end{array}$ & 0.15 & 0.30 & 1.20 & 0.012 & 0.003 & 0.30 & 0.10 & 0.15 & - & 0.011 \\
\hline
\end{tabular}


Table 2. Typical mechanical properties of applied steels [8) (ASTM and NBR standards).

\begin{tabular}{|c|c|c|c|}
\hline Steel & $\begin{array}{c}\text { YS } \\
\left(\mathrm{Kgf} / \mathrm{mm}^{2}\right)\end{array}$ & $\begin{array}{c}\text { TS } \\
\left(\mathrm{Kgf} / \mathrm{mm}^{2}\right)\end{array}$ & $\begin{array}{c}\text { Hardness } \\
\text { (HRC and HB) }\end{array}$ \\
\hline ASTM A36 & 270 & 550 & - \\
\hline High Carbon Steel & 450 & 550 & $360-400 \mathrm{HB}$ \\
\hline ASTM A709 50 & 345 & 450 & - \\
\hline Tool steel for plastic mold & 1,300 & 1,450 & $45 \mathrm{HRC}$ \\
\hline Structural steel with YS $>700 \mathrm{MPa}$ & 765 & 810 & - \\
\hline Wear resistant steel & 1,270 & 1,450 & $450 \sim 500 \mathrm{HB}$ \\
\hline $\begin{array}{l}\text { High strength structural steel with } \\
\text { good welding properties }\end{array}$ & 650 & 930 & - \\
\hline
\end{tabular}

The microstructures of the steels are shown in Figures 8-10. The high strength structural steel has ferrite and some pearlite but with a very fine grain size that guarantees higher mechanical resistance compared to the carbon steel grades, as showed by Figure 8 . The tool steel and the wear resistant steel have tempered martensite with fine carbides, which ensures their wear resistance capacity, as exemplified in Figure 10. The high strength structural steel for welding has a microstructure of tempered martensite as well.

The tool steel and the wear resistant steel have much higher yield and tensile strengths compared to the other materials, having specified hardness to guarantee wear resistance, Table 2.

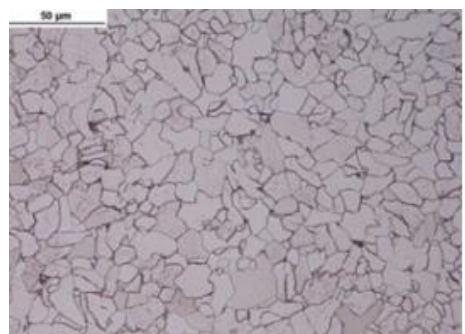

(a)

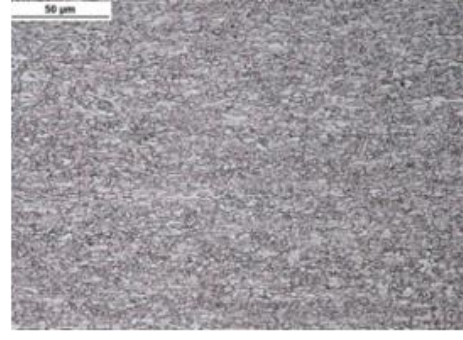

(b)

Figure 8. Carbon steel (a) and high strength structural steel with $\mathrm{YS}>700 \mathrm{MPa}$ (b). Ferrite with small regions of pearlite. For the carbon steel, the mean grain size was $9 \mu \mathrm{m}$ and for the high strength structural steel this average was $3 \mu \mathrm{m}$.

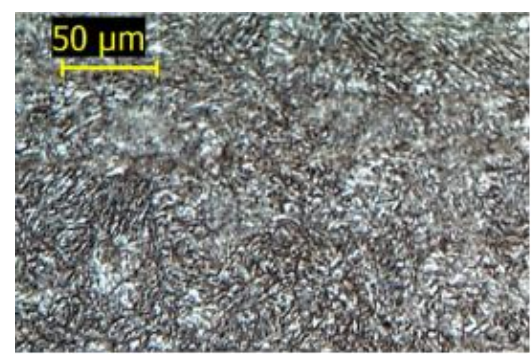

(a)

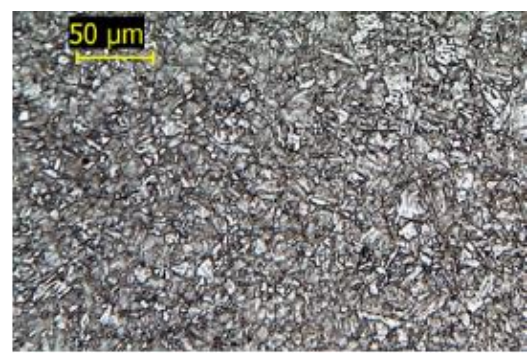

(b)

Figure 9. Microstructures of the tool steel (a) and wear resistant steel (b). Tempered martensite with fine carbides.

Chromium carbide plating is a technique used when very high wear resistance is required. The Figure 10 shows chromium plating over a carbon steel base. The as- 
cast chromium carbides were deposited on the carbon steel and solidified growing from this base metal, Figure 10. These carbides guarantee the high wear resistance of the material. This chromium-plated material was substituted with a standard wear resistant steel in order to reduce the cost of this component, motivated by the fact that excessive wear was not a factor that limited the bucket service life.

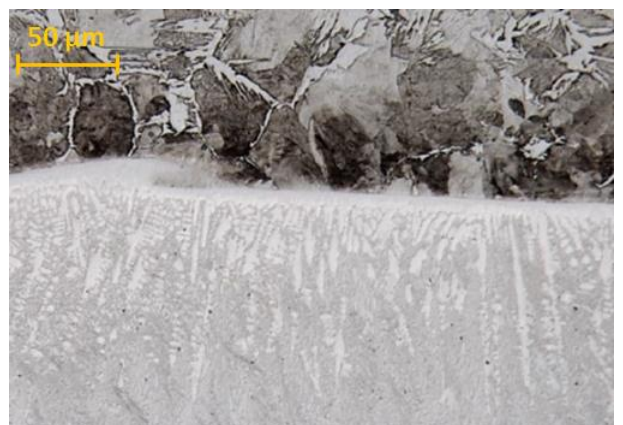

Figure 10. Microstructure of chromium carbide plated material. Upper section is the carbon steel with pearlite and acicular ferrite at the grain boundary. Bottom section is the chromium plated, as-cast microstructure.

\section{RESULTS}

\subsection{Stripped FeNb ingot loader bucket}

The new bucket design is presented in Figures 11 and 12. The 15.9-mm strip of carbon steel was substituted with a $9.5-\mathrm{mm}$ tool steel. This was the modification that was mainly responsible for reducing the weight by $25 \%$, from $364 \mathrm{Kg}$ in the original model to $274 \mathrm{Kg}$ in the new design. Volume increased by $21 \%$, from $0.24 \mathrm{~m}^{3}$ to $0.29 \mathrm{~m}^{3}$.
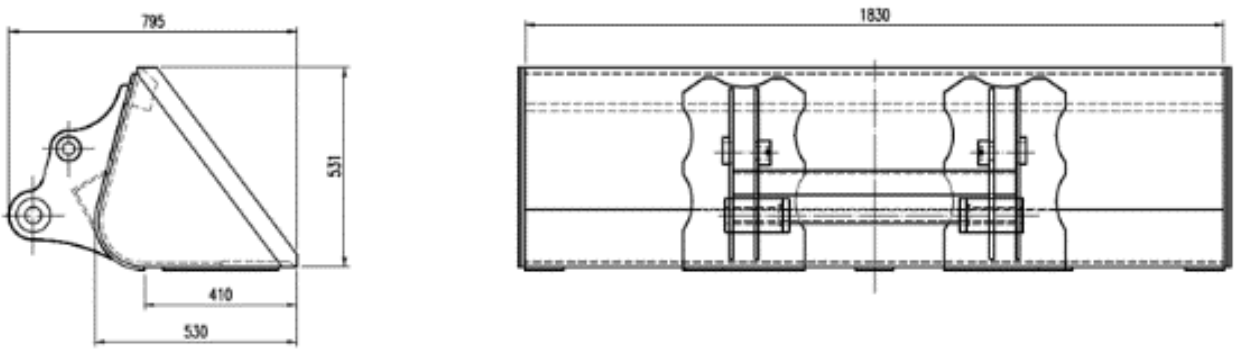

Figure 11. Main dimensions of the new bucket design. Weight $=274 \mathrm{Kg}$ and volume $=0.29 \mathrm{~m}^{3}$.
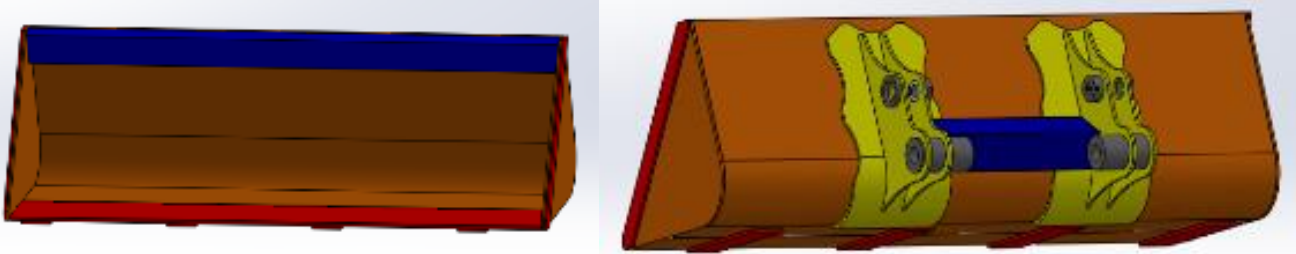

Tool steel for plastic mold (YS = $1300 \mathrm{MPa})-9.5 \mathrm{~mm}$

Wear resistant steel $(\mathrm{YS}=1200 \mathrm{MPa})-12.7 \mathrm{~mm}$

High strength structural steel for welding (YS= 700MPa) $-6.35 \mathrm{~mm}$

High strength structural steel for welding (YS= $700 \mathrm{MPa})-9.5 \mathrm{~mm}$

Figure 12. Steels used in the stripped FeNb ingot loader bucket. 
The cost of the new bucket was approximately $40 \%$ higher compared to bucket made of common steel.

To date, the new bucket has been working for 1,650 hours problem-free, which represents a $190 \%$ increase in service life over the original model, as showed by Figure 13. The carbon steel parts that were susceptible to cracking were substituted with the tool steel and the cracks that normally appeared after 200 hours are absent in the new bucket. The tool steel worked properly at the high temperatures involved when collecting hot FeNb and no deformation occurred in service, as exemplified in Figure 14. The Figures 15 and 16 present the wear surface of the bottom strip at the front of the bucket, the part that has direct contact with FeNb on the floor. Scratches and adhesions of $\mathrm{FeNb}$ are visible, as exemplified in Figures 14 and 15, and there is some corrosion, but the resulting wear does not limit the bucket life cycle.

The initial higher investment for the new bucket containing high strength steel achieved payback after 800 work hours. The cost per work hour is as follows:

- Carbon steel based design - US\$4.70/work hour

- High strength/wear resistant design - US\$2.30/work hour

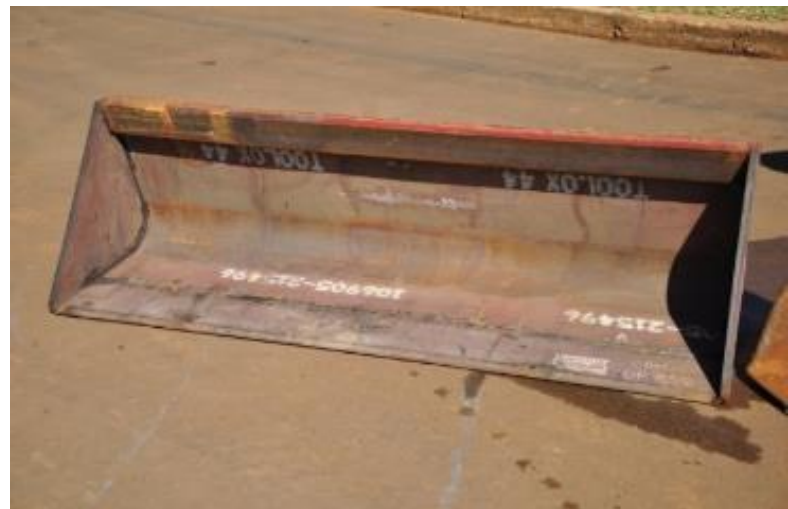

Figure 13. New bucket design after 1,650 hours of work time. No cracks and no deformation.
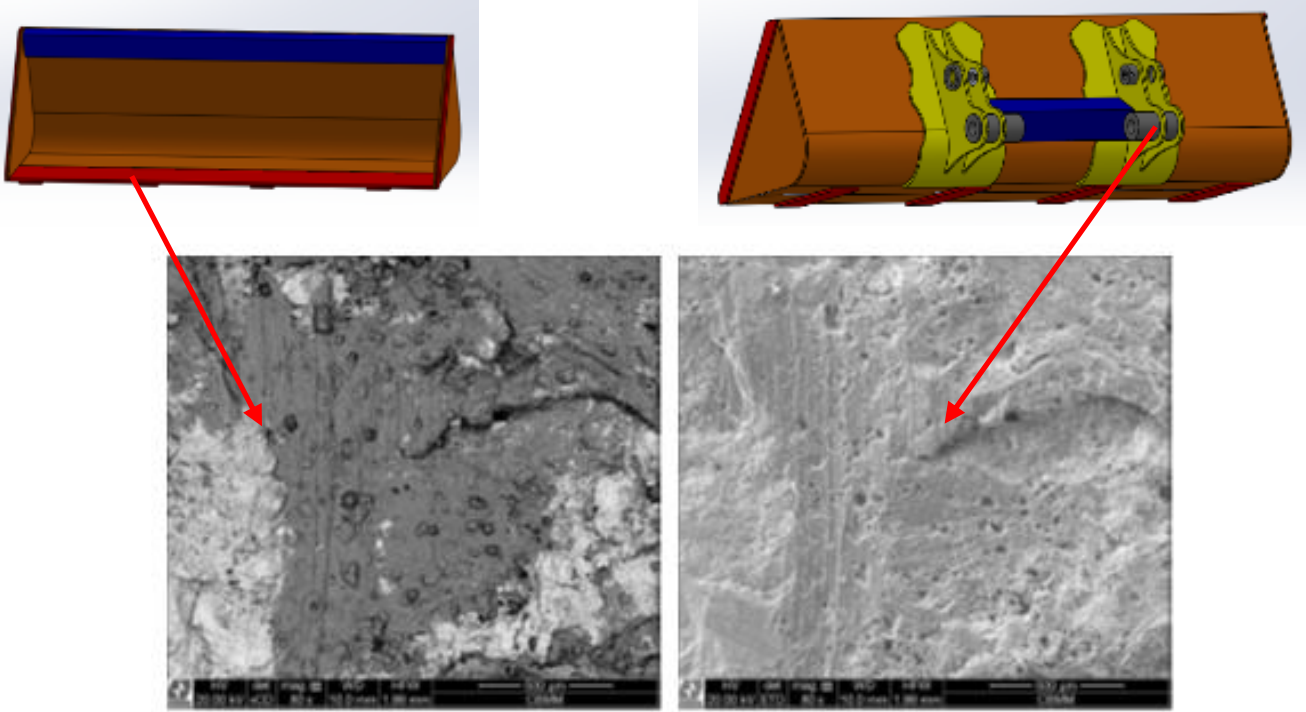

Figure 14. Abrasion surface of wear resistant steel with FeNb adhesion, scratches and corrosion. 


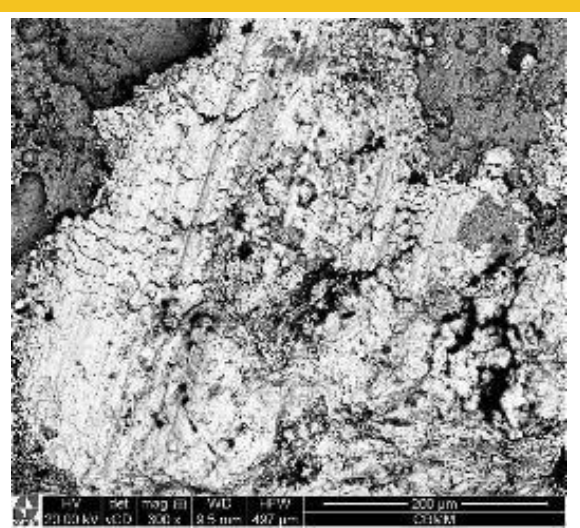

Figure 15. High carbon steel surface of wear resistant steel with FeNb adhesion, scratches and corrosion.

\subsection{The bucket used in to Niobium ore}

The new bucket has the same dimensions as the original, as shown in Figure 6. There was a $14 \%$ reduction in weight, from $3,508 \mathrm{Kg}$ to $3,013 \mathrm{Kg}$ due to reductions in thicknesses of the materials, as showed by Figure 16.

The 12.7-mm strip of chromium carbide plate was replaced by a $9.5-\mathrm{mm}$ wear resistant steel, which was primarily responsible for the weight reduction. There were no cracks and no wear in the bucket after 11,000 service hours, showing that the higher strength steels have better fatigue resistance and that the chromium carbide plate was not necessary for the type of ore transported by the loader.
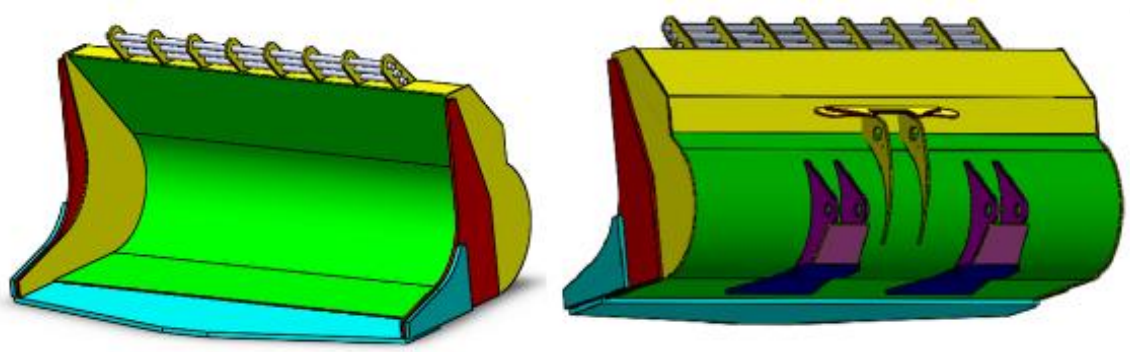

$$
\begin{aligned}
& \text { Wear resistant steel }-9.5 \mathrm{~mm} \\
& \text { Wear resistant steel }-\mathbf{3 1 . 7 5} \mathrm{mm} \\
& \text { Wear resistant steel }-\mathbf{2 2 . 2} \mathrm{mm} \\
& \text { Wear resistant steel }-\mathbf{1 9 . 0} \mathrm{mm}
\end{aligned}
$$

High strength structural steel for welding $-15.8 \mathrm{~mm}$

High strength structural steel for welding $-9.5 \mathrm{~mm}$

Figure 16. High strength and wear resistant steel used in the new niobium ore loader bucket.

The payload capacity increased by $4.7 \%$ while maintaining the maximum load allowed by manufacturer specifications. With the $495-\mathrm{Kg}$ reduction in the bucket weight, it was possible to increase payload from $10,370 \mathrm{Kg}$ to $10,865 \mathrm{Kg}$. Given the impossibility of working at the maximum allowed limit, this increase in payload made it possible to fill a 42 -tonne capacity mine truck with four buckets wheel loaders to $97 \%$ nominal capacity. The original design bucket required more than four buckets wheel loaders to fill the truck. 
The investment cost of the original bucket was US\$20,606. For the new design, since the plates treated with chromium carbide were replaced with a single wear resistant steel, the investment cost was reduced by $7.0 \%$ to US $\$ 19,090$.

\section{CONCLUSION}

The application of high strength steels and a temperature resistant tool steel in loader buckets wheel loaders for stripped FeNb ingot made it possible to:

- Reduce bucket weight by $25 \%$.

- Increase bucket volume by $21 \%$.

- Eliminate deformation caused by high temperatures.

- Eliminate structural cracks in the bucket, increasing service life by about $190 \%$ to date.

- Reduce the cost of investment per work hour from US\$4.70/h with the carbon steel design to US\$2.30/h for the high strength steel design.

The following was achieved in the niobium ore loader bucket:

- Reduce bucket weight by $14 \%$.

- Eliminate cracks even after 11,000 work hours, demonstrating that the higher strength steels have better fatigue resistance. There was no wear, indicating that the chromium carbide plate was not necessary for the type of ore transported by the loader bucket.

- Increase payload capacity by $4.7 \%$ while maintaining the maximum allowable load per manufacturer specifications. With this, four bucket loads were sufficient to fill the 42-tonne mine truck, allowing this process to be more productive.

- Reduce investment cost by $7.0 \%$.

\section{Acknowledgment}

We appreciate the unconditional support given by the board of Companhia Brasileira de Metalurgia e Mineração - CBMM, which spared no efforts to make this project was implemented and consolidated. I emphasize the thanks, especially for their confidence in the people who led the project.

\section{REFERENCES}

1 Streisselberger, A.; Schwinn, V.; Hubo, R. - Microalloyed Structural Plate Rolling Heat Treatment and Application. International Conference Niobium 2001, Orlando, USA, 2001.

2 Donnay, B.; Grober, H. Niobium in High Strength Weldable Beams and Other Structures. International Conference Niobium 2001, Orlando, USA, 2001.

3 Silvestre, L.M.; Pimenta, R.; Nogueira, M.A.S.; Queiroz, L.; Salles, H.; Jordao, A.; Ribeiro, R.; Pimenta, M.; Conceicao, J.; Rocha, L.; Buratto, F.; Fonseca, E. High Strength Steel As a Solution for the Lean Design of Industrial Buildings. Value-Added Niobium Microalloyed Construction Steel Symposium, Singapore, 2012.

4 Olsoon, K.; Gladh, M.; Hedin, J.E.; Larsoon, J. - Niobium Microalloyed Sheet Steels for Automotive Applications - Microalloyed High Strength Steels for Reduced Weight and Improved Crash Performance in Automotive Applications - TMS (The Minerals, Metals \& Materials Society), 2006. 
5 Rosa, H.L. et al - Increasing Transportation Efficiency by Using High Strength Niobium Microalloyed Steel for Truck Dumpers - International Seminar of Application of High Strength Steels in the Lightweight Design of Commercial Vehicles, São Paulo, 2013.

6 Hulka, K.; Kern, A.; Schriever, U. - Application of Niobium in Quenched and Tempered High-Strength Steels, Materials Science Forum Vols. 500-501, 2005 pp 519-526.

7 Ishikawa, N.; Ueda, K.; Mitao, S.; Murota, Y.; Sakiyama, T. - High-Performance AbrasionResistant Steel Plates with Excellent Low-Temperature Toughness; 2011 International Symposium on the Recent Developments in Plate Steels.

8 SSAB Brochure:

http://www.ssab.com/Global/Plate/Brochures/en/041_SSAB_plate_general_product_infor mation_UK.pdf. 